\title{
Towards a Character Language: A Probability in Language Use
}

\author{
Jumanto \\ Faculty of Cultural Studies (FIB), Dian Nuswantoro University, Semarang, Indonesia \\ Email: ilhamjwwp@yahoo.com \\ Received 25 February 2014; revised 2 April 2014; accepted 9 April 2014 \\ Copyright (C) 2014 by author and Scientific Research Publishing Inc. \\ This work is licensed under the Creative Commons Attribution International License (CC BY). \\ http://creativecommons.org/licenses/by/4.0/

(c) (i) Open Access

\section{Abstract}

This opinion paper is about a probability in language use, about how a competent speaker should be aware of speaking for politeness or for camaraderie, and be capable of avoiding impoliteness. The main aspects of pragmatics are briefly introduced and then elaborated as building-blocks of character language. The proposed building blocks are: 1) elaboration of meaning and form strategies, 2) distant language and close language strategies, 3) politeness and camaraderie strategies, 4) object language and metalanguage strategies. A view on character language in Indonesian context is given, on how politeness, camaraderie, and impoliteness are elaborated; and then, six phases of character language building are proposed as a verbal social project: 1) interaction phase, 2) teaching-and-learning process phase, 3) evaluation phase, 4) re-evaluation phase, 5) verification phase, 6) selection phase. Upon the completion of a character language building, a competent speaker is presumably well-equipped for using language in a particular situation that may call.

\section{Keywords}

Verbal Interaction, Politeness, Camaraderie, Social Distance, Object Language, Metalanguage, Character, Language Use, Probability, Rude Situation, Awkward Situation, Character Language

\section{Introduction}

I am not very sure whether this idea works or not, despite my preference or earnest hope on the former to the latter. Rather than standing idle imagining what I have been thinking about for years upon completion of my $\mathrm{PhD}$ in Linguistics (Pragmatics) from University of Indonesia (Jumanto, 2006), (Jumanto, Phatic Communication among English Native Speakers, 2008), and after considering the article in an international journal (Jumanto, Phatic Communication: How English Native Speakers Create Ties of Union, 2014), this writing of article has recently come into being. I have been thinking about the development of linguistics so far, and a thought has 
tempted me whether this thesis can affect the linguistic world we live in or not, whether what I am heading for is indeed there in a speech society or not, and whether what I have in mind is true or not. However, as I once presented this topic in an international conference on English Language Teaching(ELT) in $2011^{1}$, and, in the following year, in an international BIPA (Indonesian for Non-Native Speakers) Conference in 2012 $2^{2}$, both held in distinguished private universities in Indonesia, I found out that, not unexpectedly, because people kept talking about how character students should be in the language teaching and character building in the 2011 conference, and because people talked more about Indonesian language teaching (BIPA) in the 2012 conference-both missed the talk about language with character-this raw concept of thesis did not find its path.

I have myself observed that the development of linguistics has been quite a bitter quarrel between formal linguistics and functional linguistics. I see that it is of no problem, just like two siblings have different opinions for the betterment of their home. Something missing was together searched on by the two siblings. The search on meaning has its long history, side by side with that on form. The search on form, in my observation, has developed the so-called formal linguistics; and on the other hand, the search on meaning has contributed to the development of functional linguistics. Though the search on meaning has long been done since de Saussure (de Saussure, 1916) and Peirce (Peirce, 1940) in the early 1900, Bühler (Bühler, 1918), Malinowski (Malinowski, 1923), and Morris (Morris, 1946) and Jakobson (Jakobson, 1960), it has been interrupted by the search of form since Bloomfield (Boomfield, 1930), Fries (Fries, 1979), and Chomsky (Chomsky, 1950). The search on meaning was then revived by Austin with his speech acts theory (Austin, 1957), and then advocated by Searle (Searle, 1965), i.e. pragmatics, a branch of functional linguistics we can enjoy learning today. This cultural perspective on language use has been elaborated by functional linguists, e.g. Halliday (Halliday, Language as Social Semiotic, 1978), Lincoln and Guba (Lincoln \& Guba, 1985), Holmes (Holmes, 1992), Thompson (Thompson, 1997), and Hinkel (Hinkel, 1999), to mention a few.

I have been long interested in the fact that our linguistic founding fathers have developed linguistics functionally, i.e. how they blended or combined linguistics and some other discipline into what we have heard or followed or advocated today, i.e. sociolinguistics, psycholinguistics, neurolinguistics, or some other branch with the-linguistics suffix. Here, the meaning carried out by a particular form or text is elaborated into or is made to function in a particular discipline. Thus, sociolinguistics has been a blend of sociology and linguistics, psycholinguistics of psychology and linguistics, neurolinguistics of neurology (medicine) and linguistics, and some other blend of a particular discipline and linguistics.

In this very sense, I have been aware of the fact that speakers are indeed bound to context, one property of which is when we are speaking to a close hearer or a distant hearer. Types of hearer then come into effect due to this sense. Brown and Gilmanhave elaborated this thesis with their grand article The pronouns of power and solidarity (Brown \& Gilman, 1968). I myself have made a little benefit of their findings when researching Phatic communication among English native speakers (Jumanto, 2006), on how it functions differently to different types of hearer and on what types of form the English native speakers elaborated to show politeness or friendship.

Politeness and friendship (or better: camaraderie) have become a central issue in what has tempted me for years, whether language use is to hearers with power factor or whether it is to hearers with solidarity factor. This far, we have come to the so-called distant language or close language (Jumanto, Teaching a Character BIPA (Indonesian for Non-Native Speakers), 2012). Distant language brings politeness, and close language brings camaraderie. This is, then, leading to what I am now proposing to the world as character language, the proposal of which is probably lacking advocation, but is hopefully getting a little attention.

In this article, we are talking about character language, or about politeness and camaraderie in language use, or about politeness or impoliteness in language use, i.e. about a probability in language use. Language use is, we believe together, a matter of probability, advocating the properties of language use, or communicative competence, first introduced by Hymes in the late 1960s (Hymes, On communicative competence, 1972); (Duranti, 1998). Meanwhile, the text analysis here employs Indonesian language corpus data, the researcher's opinion of which is based on three academic facts: 1) that the researcher is an Indonesian native speaker, 2) that the data collection as well as the direct observation is more authentic around the researcher's daily Indonesian-speaking atmosphere, and 3) that languages, commonly believed by formal as well as functional linguists, are most prob-

\footnotetext{
${ }^{1}$ Jumanto, J. (2011c). Pragmatics and Character Language Building. The 58th TEFLIN International Conference on Language Teaching and Character Building (pp. 329-340). Semarang, Indonesia.

${ }^{2} J u m a n t o$, J. (2012). Teaching a Character BIPA (Indonesian for Non-Native Speakers). The 2012 KIPBIPA VIII-ASILE International Conference (pp. 1-20). Salatiga, Indonesia.
} 
ably universal around the world.

\section{Character Language}

A character language is a language with a character. The word character, in one sense, refers to nature, quality, of a thing (OLPD, 1987) or to ability, qualities, validity (CALD, 2008). A character language thus is able to function as a means of communication (ability), has qualities with which the language is different from the others (quality), and is effective in a correct formality (validity).

A character language should function as a means of communication, i.e. human communication, interpersonal and social. In an interpersonal communication, a character language should consider the speakers, the values and idiosyncrasies they believe in and hold, and their background knowledge as well. This is an interpersonal context. A character language should also involve the social values and norms, and other social aspects the speakers may elaborate in their verbal interactions. This is a social context. Thus, to be able to function as a means of communication, a character language should consider the interpersonal context and the social context of the speakers involved in verbal interactions. This is the first content: ability.

The second content of a character language is qualities. Qualities in this case may refer to everything special which distinguishes a particular language from the others. Thus, a language with a character is then a language distinguishable from the other languages. In this sense, a character language is unique despite some universal aspects of languages in the world. Here, we can say that a character language has an identity.

The third content of a character language is validity. Validity in this case may refer to effectiveness in a correct formality (CALD, 2008). Formality refers to high or strict attention to rules, forms, and convention we hold and believe in together in society. Informality then does the reverse. In this light, a character language should have formal forms and informal forms. Formal forms are high forms (or of high variety) and informal forms are low forms (or of low variety).

High and low varieties of language exist in some speech society, as they meet the demands of verbal interacttions of the members. Here, we are speaking of a diglossic situation. A diglossic situation in a speech society is a situation where people usually speak two varieties or variants of their language, i.e. high language and low language, or for more ease to say, formal language and informal language.

From the accounts above, we can finally sum up here that a character language is a language which can function as a means of communication in a diglossic situation, i.e. either in formal situations or in informal situations.

Is English a character language? Is Indonesian a character language? Is your language a character language? What is a character language to do with pragmatics? What is pragmatics to do with a character language? How do we build a character language through pragmatics? These are questions to deal with in this opinion paper.

\section{Pragmatic View on Character Language}

To begin with, let us talk about some significant pragmatic aspects here, i.e. interaction of meanings, form in pragmatics, distant language and close language, politeness and camaraderie, and object language and metalanguage. The aspects are to be discussed in the accounts below.

\subsection{Pragmatics and Interaction of Meanings}

Pragmatic linguistics or linguistic pragmatics or, for short, pragmatics is not merely talking about locution, illocution, or perlocution. It inevitably is. A speech is an act with the three meanings, i.e. locutionary, illocutionary, and perlocutionary meanings. In pragmatics, this each meaning can be a force, an illocutionary or a pragmatic force. We are speaking and doing something at the same time, or to be more pragmatically specific: we do the act of saying something, implying something, and affecting someone at the same time. In the context that a speaker is talking to a cold wall or even a beautiful statue, or is speaking alone (soliloquy), we miss the perlocution. This is what Austin has elaborated in his grand theory of speech acts How to Do Things with Words (Austin, 1957). Austin's elaboration of speech acts theory is, in the writer's opinion, in line with Malinowski's argument that language is a mode of action (Malinowski, 1923).

Pragmatics is of human interactions every day (pragmeme $=$ a human act (Mey, 2001)). Pragmatics is about interaction of meanings (Thomas, 1996); (Jumanto, Pragmatics: Linguistic World is Broad, 2011b). Though the 
search of meaning has long been done since de Saussure and Peirce in the early 1900, Bühler (Bühler, 1918), Malinowski (Malinowski, 1923), and Morris (Morris, 1946), it has been interrupted by the search of form since Bloomfield (Boomfield, 1930), Fries (Fries, 1979), and Chomsky (Chomsky, 1950). The search of meaning was then revived by Austin with his speech acts theory (Austin, 1957), and then advocated by Searle (Searle, 1965).

Pragmatics is the study of language use within context. Language use or spoken/written communication is a discourse (Richards, Platt, \& Platt, Longman Dictionary of Language Teaching and Applied Linguistics, 1985); (Mey, 2001); (CoBuild CoBuild English Dictionary, 2003); (Jumanto, Discourse Analysis and Ideology Critics, 2011a). Utterances are the concrete forms of language use which we analyze as text (Carter, 1997). The analysis of pragmatics is then basically a discourse analysis on text within context (Cook, 1989); (Schiffrin, 1994); (Mey, 2001); (Jumanto, Pragmatics: Linguistic World is Broad, 2011b). Pragmatics is thus the study of meaning of language use in communication between the speaker and the hearer, within context, i.e. linguistic context and context of situation, in a particular speech society (Jumanto, Pragmatics: Linguistic World is Broad, 2011b).

Pragmatics regards communication as interaction of meanings, not interaction of forms. However, form or text is important as the vehicle of meaning. Without the form or text, language use or communication or discourse never happens, as there is nothing to be perceived or there is no text (Jumanto, Pragmatics: Linguistic World is Broad, 2011b).

The meaning (explicature or implicature) interacted in pragmatics is later developing or is open to probable elaboration by the speaker into the so-called ideology and then the myth. Here, the vehicles of meaning are not only an utterance or a speech act (or an idio text), but also an ideo text (a text bearing an ideology of a particular societal group or a political party) and a socio text (a text bearing an ideology of a particular society) (Jumanto, Language of Advertising: An Ideology Critic, 2010); (Jumanto, Discourse Analysis and Ideology Critics, 2011a).

How does pragmatics deal with form to find out meaning, as the form is the vehicle of meaning? To come to this answer, let us observe the account below.

\subsection{Form in Pragmatics}

Forms of utterance in pragmatics can be observed in three dichotomy types: 1) formal-informal, 2) direct-indirect, and 3) literal-non literal (Jumanto, Pragmatics and Character Language Building, 2011c). The word "formality" refers to high or strict attention to rules, forms, and convention (Hornby, 1987), and, therefore, informality does the reverse. Formal utterances have more complete, longer forms, and are in a good order. Informal utterances have incomplete, shorter forms, and are not in a good order, and sometimes cut-down, reversed-up, and changed in favor of the speaker.

Direct utterances are the utterances whose meanings can be soon interpreted directly from parts of the utterances, i.e. the meanings based on linguistic context (cohesive meanings). This meaning is called explicature in pragmatics. The opposite of this is called implicature. Implicatures are the meanings of indirect utterances, i.e. the meanings based on context of situation (coherent meanings). To come to an implicature of an indirect utterance, a hearer usually thinks a bit longer than he does to an explicature of a direct utterance.

Similar to direct and indirect utterances are literal and non-literal utterances. Literal utterances are the utterances in their usual and obvious sense. The opposite is non-literal or figurative utterances. Non-literal utterances use allegories and metaphors. Allegories are stories, paintings, or descriptions of ideas such as anger, patience, purity, and truth by symbols of persons with those characters. Metaphors are imaginative ways to describe something by referring to something else with the similar characteristics or qualities. A metaphoric language is thus the language with no usual or literal meaning but the language which describes something by images or symbols. Direct and literal utterances include banter, while indirect and non-literal utterances involve irony and hedges (Leech, 1983); (Jumanto, Pragmatics and Character Language Building, 2011c).

How do forms of utterance affect the meanings in pragmatics? Let us talk about distant language and close language in the next account.

\subsection{Distant Language and Close Language}

Distant language and close language here refer to and derive from the notion social distance. Social distance is the physical as well as psychological distance between the speaker and the hearer (Jumanto, Pragmatics: Linguistic World is Broad, 2011b). Social distance is not distant or close. It is a flexible concept of relative rela- 
tionship between the speakers. Social distance is assumed to be zero when the speaker is talking to themselves ${ }^{3}$.

From this context, pragmatics regards a diglossic situation of a speech society as having two variants of language, i.e. distant language and close language. Distant language refers to formal, indirect, and non-literal utterances, while close language refers to informal, direct, and literal utterances. As referring to formal, indirect, and non-literal utterances, distant language is usually carefully elaborated and uses safe and common topics. Meanwhile, as referring to informal, direct, and literal utterances, close language usually involves contractions, slangs, reverse-ups, changes, taboos, swearing, f-words, and uses any topics, personal and private (Axtell, 1995). The speaker tends to use distant language to the hearers with power factor (superiors); on the other hand, the speaker tends to use close language to the hearers with solidarity factor (close hearers) ${ }^{4}$.

What are distant language and close language to do with politeness? Please watch our manners and read the following account carefully.

\subsection{Politeness and Camaraderie}

Considering the summary critique of politeness theories by Gino Eelen (Eelen, 2001), and apart from various theories of politeness (Leech, 1983; Brown \& Levinson, 1987; Spencer-Oatey, 1992; Lakoff, 1990; Fraser \& Nolen, 1981; Gu, 1990; Ide, 1989; Blum-Kulka, 1992; Arndt \& Janney, 1985; Watts, 1989; Thomas, 1996; Coupland, 2000) Jumanto is trying to define what politeness is (Jumanto, Pragmatics: Linguistic World is Broad, 2011b). Jumanto proposed a theory of politeness among Javanese speakers, advocating the theory of Gunarwan (Gunarwan, Implicatures of Linguistic Codes Selection in some dialogues of Ludruk, 2001). Many of the politeness theories above are the results of violating Grice's Cooperative Principles (Grice, 1975), though some proposed a new atmosphere. However, few have proposed a working definition of politeness. Jumanto tried to offer a definition that politeness is everything good that has been uttered as well as acted by the speaker to the hearer within a particular context, to maintain their interpersonal face as well as their social face (Jumanto, Pragmatics: Linguistic World is Broad, 2011b).

The notion of face in politeness has come into high attention and importance since it was borrowed by Brown and Levinson (Brown \& Levinson, 1987) from Goffman (Goffman, 1959, 1967). In Goffman's grand theory, everyone in interaction has two faces, positive face and negative face. Face refers to the will, intention, and other associations of ideas and values in the self of the speaker. In short, positive face refers to appreciation of the speaker's self and negative face refers to no depreciation of the speaker's self. The elaboration of face by Brown and Levinson has resulted in face management for two major politeness strategies, positive politeness strategies (which refer to positive face) and negative politeness strategies (which refer to negative face).

Under the light of this face management theory, Jumanto (Jumanto, Pragmatics and Character Language Building, 2011c) argues that the politeness theories in verbal interactions fall into or lead to two major poles, i.e. one is directed to distancing politeness and the other is directed to closeness politeness. Distancing politeness refers to Goffman's negative face (Goffman, 1959), Brown and Levinson's negative politeness strategies (Brown \& Levinson, 1987), Renkema's respect politeness (Renkema, 1993), and Jumanto's politeness (Jumanto, Phatic Communication among English Native Speakers, 2008); (Jumanto, Pragmatics: Linguistic World is Broad, 2011b). Closeness politeness, on the other hand, refers to Goffman's positive face (Goffman, 1959), Brown and Levinson's positive politeness strategies (Brown \& Levinson, 1987), Renkema's solidarity politeness (Renkema, 1993), and Jumanto's friendship or camaraderie (Jumanto, Phatic Communication among English Native Speakers, 2008); (Jumanto, Pragmatics: Linguistic World is Broad, 2011b). This tendency has been wellstrengthened and highlighted by the results of Jumanto's research on phatic communication among English native speakers (Jumanto, 2006).

From the accounts above, with high gratitude to the former theorists and researchers, we can see clearly that distancing politeness and closeness politeness are in line with distant language and close language the writer has just proposed above. Here, so far so good, we can sum up that distant language brings politeness, and close language brings friendship or camaraderie. Distant language and close language to show politeness and camaraderie finally meet the demand of language as a means of communication, i.e. a real-life everyday use of language in all situations or pragmatic use of language in a diglossic situation.

\footnotetext{
${ }^{3}$ An inspiring opinion given by Professor Asim Gunarwan, during his pragmatic classes, at University of Indonesia, in 2002-2006.

${ }^{4}$ Types of hearer can be further seen in Brown and Gilman (1968) or Brown and Gilman in Jumanto (2011b).
} 
A BIG QUESTION is rising here: HOW DOES PRAGMATICS BUILD A CHARACTER LANGUAGE? Please wait a minute and be patient. We still have to deal with object language and metalanguage below.

\subsection{Object Language and Metalanguage}

The subtitle above of the two levels of language has long been advocated by de Saussurians and Peircians since early 1900. Indeed, as grand theorists of the states of the linguistic arts, their influences have persisted in linguistic areas to date. The first level of language function is called object language. This level is also noted as denotative level, which is the usual and obvious sense of language, based on some convention, which is objecttive. In this level, language is seen as an object (object language). The word RAT in this level, for example, refers to an animal, i.e. a four-footed mammal of the rodent family.

The second level of language is called metalanguage. This level is also noted as connotative level, which is the level of additional meaning to give an image or imagination based on some convention, which is subjective. This metalanguage level is metaphorical. A metaphor, as mentioned above, is an imaginative way to describe something by referring to something else with the similar characteristics or qualities. The word RAT in this level, for example, may be used to describe a person who breaks or deserts the duty. In this similar context, for another example, the word HEART as object language is the center of blood circulation in the human body, but the word HEART as metalanguage may refer to somebody the speaker is in love with.

Object language and metalanguage, the writer argues, exist in every living language in this world, the two levels of which serve human language as a means of communication, within interpersonal or social context.

Now we are coming to the discussions of character language below. However, before we are talking about the building of it, let us talk about the probability of it.

\section{Character Language: A Probability in Language Use}

This heading is indeed intriguing. Why language use is a probability is now coming into our attention. As have been mentioned above, the talk on character language comprises politeness, camaraderie, and awareness of potential rude situations and awkward situations to happen in verbal interactions. In this light, we are about to observe how character language is elaborated in Indonesian context. Here, cases of politeness and impoliteness in Indonesian language are taken into account. A preliminary view on types of utterances in Indonesian language is given as leading points to politeness and camaraderie.

\subsection{Character Language: Cases of Politeness and Impoliteness in Indonesian Language}

The presentation of politeness and camaraderie in Indonesian language here means discussing politeness and camaraderie in the Indonesian languages. Politeness and camaraderie in Indonesian language is basically the language use in form of everyday verbal interactions, so that distant language and close language are there in real-life practices in the Indonesian diglossic speech situation. The pragmatic aspects discussed above are applied here, i.e. 1) elaboration of meaning and form, 2) distant language and close language, 3) politeness and camaraderie, 4) object language and metalanguage. The four pragmatic aspects are as the building blocks of politeness and camaraderie in Indonesian language, the discussion of which is carried out through two major accounts below.

\subsubsection{Types of Utterances in Indonesian Language}

The talk on types of utterances in Indonesian language consists of three sub-points, i.e. 1) formality-based utterances, 2) directness-based utterances, and 3) meaning-based utterances.

1) Formality-Based Utterances

Formality-based utterances in the Indonesian language discussed here may fall into two categories, i.e. formal utterances and informal utterances. Formal utterances tend to have more complete, longer forms, and are in a good order. Whereas, informal utterances have incomplete, shorter forms, and are not in a good order, and sometimes cut-down, reversed-up, and changed in favor of the speaker. The two variants can be illustrated in Table 1 .

Examples in shorter utterances can also be found in daily use, as illustrated in Table 2.

2) Directness-Based Utterances 
Table 1. Formality-based utterances.

Formal utterances

Informal utterances

Saya mengucapkanterima kasih banyak. "I thank you very much"

Terima kasih; Makasih; Kamsia; Tks; Thanks; Thx "Thank you"; "Thanks"; "Thx"

Table 2. More examples on formality-based utterances.

\begin{tabular}{|c|c|}
\hline Formal utterances & Informal utterances \\
\hline $\begin{array}{l}\text { memberikan } \\
\text { "giving"; "give them" }\end{array}$ & $\begin{array}{l}\text { berikan; beri; kasihkan; kasih } \\
\text { "givin"; "giv'em" }\end{array}$ \\
\hline $\begin{array}{l}\text { Selamat pagi! } \\
\text { "Good morning!" }\end{array}$ & $\begin{array}{l}\text { Met pagi!; Pagi! } \\
\text { "Morning!" }\end{array}$ \\
\hline $\begin{array}{l}\text { Semoga Anda segera sembuh } \\
\text { "May you get better soon" }\end{array}$ & $\begin{array}{l}\text { Cepet sembuh; Cepet baikan; Lekas sehat } \\
\text { "Get better soon"; "Better soon" }\end{array}$ \\
\hline $\begin{array}{l}\text { membantu } \\
\text { "helping"; "help them" }\end{array}$ & $\begin{array}{l}\text { mbantu; bantu } \\
\text { "helpin"; "help'em" }\end{array}$ \\
\hline $\begin{array}{l}\text { lelah sekali } \\
\text { "extremely tired" }\end{array}$ & $\begin{array}{l}\text { capek banget; ka-o; ngos-ngosan } \\
\text { "exhausted" }\end{array}$ \\
\hline $\begin{array}{l}\text { berlebihan } \\
\text { "superfluous" }\end{array}$ & $\begin{array}{l}\text { lebay } \\
{[?]}\end{array}$ \\
\hline $\begin{array}{l}\text { jarang dibelai } \\
\text { "seldom cared for" }\end{array}$ & $\begin{array}{c}\text { jablay } \\
{[?]}\end{array}$ \\
\hline $\begin{array}{l}\text { tidak } \\
\text { "No, I do not" }\end{array}$ & $\begin{array}{l}\text { tak; tdk; nggak; gak } \\
\text { "No"; "I don't"; "don't" }\end{array}$ \\
\hline $\begin{array}{c}\text { meskipun } \\
\text { “although"; "even though" }\end{array}$ & $\begin{array}{l}\text { meski; mskpn } \\
\text { "though" }\end{array}$ \\
\hline $\begin{array}{c}\text { tetapi } \\
\text { "however", "nevertheless" }\end{array}$ & $\begin{array}{l}\text { tapi; tp; but } \\
\text { "but" }\end{array}$ \\
\hline $\begin{array}{l}\text { ayah } \\
\text { "father" }\end{array}$ & $\begin{array}{l}\text { yah; papa; daddy; bokap } \\
\text { "daddy", "dad" }\end{array}$ \\
\hline $\begin{array}{c}\text { ibu } \\
\text { "mother" }\end{array}$ & $\begin{array}{l}\text { bu; mama; mammy; nyokap } \\
\text { "mommy"; "mom" }\end{array}$ \\
\hline $\begin{array}{l}\text { Bapak Budi } \\
\text { "Mister Budi" }\end{array}$ & $\begin{array}{l}\text { Pak Budi; P Budi } \\
\text { "Mr. Budi" }\end{array}$ \\
\hline $\begin{array}{c}\text { Ibu Rini } \\
\text { "Mistress Rini" }\end{array}$ & $\begin{array}{l}\text { Bu Rini; B Rini } \\
\text { "Ms. Rini" }\end{array}$ \\
\hline $\begin{array}{c}\text { Saya } \\
\text { "I would } . . "\end{array}$ & $\begin{array}{l}\text { Aku; Gue; Ai; Ike } \\
\text { "I will ..." }\end{array}$ \\
\hline $\begin{array}{c}\text { Anda } \\
\text { "You would } . . . "\end{array}$ & $\begin{array}{l}\text { Kamu; Lu; Situ; You } \\
\text { "You will..." }\end{array}$ \\
\hline $\begin{array}{c}\text { Saudara } \\
\text { "You would } \cdots "\end{array}$ & $\begin{array}{c}\mathrm{Sdr} \\
\text { "You will } \cdots "\end{array}$ \\
\hline $\begin{array}{l}\text { dan sebagainya } \\
\text { "et cetera" }\end{array}$ & $\begin{array}{l}\text { dsb } \\
\text { "etc." }\end{array}$ \\
\hline
\end{tabular}


Directness-based utterances in the Indonesian language may also fall into two categories, i.e. direct utterances and indirect utterances. Direct utterances are the utterances whose meanings can be soon interpreted directly from parts of the utterances, i.e. the meanings based on linguistic context (cohesive meanings). This meaning is called explicature in pragmatics. The opposite of this is called implicature. Implicatures are the meanings of indirect utterances, i.e. the meanings based on context of situation (coherent meanings). To come to an implicature of an indirect utterance, a hearer usually thinks a bit longer than he does to an explicature of a direct utterance. The two variants can be illustrated in Table 3 .

Other examples of direct and indirect utterances can also be found in daily use, as illustrated in Table 4.

3) Meaning-Based Utterances

Meaning-based utterances in the Indonesian language may also fall into two categories, i.e. literal utterances and non-literal utterances. Literal utterances are the utterances in their usual and obvious sense. The opposite are non-literal or figurative utterances. Non-literal utterances use allegories and metaphors (CALD, 2008). Allegories are stories, paintings, or descriptions of ideas such as anger, patience, purity, and truth by symbols of persons with those characters. Metaphors are imaginative ways to describe something by referring to something else with the similar characteristics or qualities. A metaphoric language is thus the language with no usual or literal meaning but the language which describes something by images or symbols. Direct and literal utterances include banter, while indirect and non-literal utterances involve irony and hedges (Leech, 1983); (Jumanto J., Pragmatics and Character Language Building, 2011c). The two variants can be illustrated in Table 5.

Other examples of literal and non-literal utterances can also be found in daily use, as illustrated in Table 6.

\subsubsection{Politeness and Camaraderie in Indonesian Language}

Politeness is everything good that has been uttered as well as acted by the speaker to the hearer within a particular

Table 3. Directness-based utterances.

\begin{tabular}{cc}
\hline Direct utterances & Indirect utterances \\
\hline $\begin{array}{c}\text { Saya tidak setuju dengan Anda. } \\
\text { "I do not agree with you" }\end{array}$ & $\begin{array}{l}\text { Menurut saya, sebaiknya begini } \cdots \\
\text { "I think that it is better like this } \cdots "\end{array}$ \\
\hline
\end{tabular}

Table 4. More examples on directness-based utterances.

\begin{tabular}{|c|c|}
\hline Direct utterances & Indirect utterances \\
\hline $\begin{array}{l}\text { Saya sedang sibuk dan tidak bias diganggu sekarang. } \\
\text { "I am busy. You should not disturb me now" }\end{array}$ & $\begin{array}{l}\text { Bagaimana jika besok saja? } \\
\text { "What if we do this tomorrow?" }\end{array}$ \\
\hline $\begin{array}{l}\text { Tolong hidupkan AC-nya! } \\
\text { "Please turn on the AC!" }\end{array}$ & $\begin{array}{l}\text { Ruangannya kok panas, ya. } \\
\text { "It is hot here, isn't it?" }\end{array}$ \\
\hline $\begin{array}{l}\text { Cinta mereka tidak serius. } \\
\text { "Their love is not very serious" }\end{array}$ & $\begin{array}{l}\text { Mereka sedang cinta monyet. } \\
\text { "They are in puppy love" }\end{array}$ \\
\hline $\begin{array}{l}\text { Panggilkan Pak Kebun! } \\
\text { "Call the gardener!" }\end{array}$ & $\begin{array}{l}\text { Pak Kebun di mana, ya? } \\
\text { "Where is the gardener?" }\end{array}$ \\
\hline $\begin{array}{l}\text { Saya tidak minum kopi. } \\
\text { "I do not drink coffee" }\end{array}$ & $\begin{array}{l}\text { Bisa minuman yang lain? } \\
\text { "Do you have something else to drink?" }\end{array}$ \\
\hline $\begin{array}{l}\text { Lama. } \\
\text { "Long time" }\end{array}$ & $\begin{array}{l}\text { Tidak sebentar. } \\
\text { "Not a short time" }\end{array}$ \\
\hline $\begin{array}{l}\text { Terlambat. } \\
\text { "Late" }\end{array}$ & $\begin{array}{l}\text { Tidak tepat waktu. } \\
\text { "Not on time" }\end{array}$ \\
\hline $\begin{array}{l}\text { Bodoh. } \\
\text { "Stupid" }\end{array}$ & $\begin{array}{l}\text { Tidak begitu pintar. } \\
\text { "Not very smart" }\end{array}$ \\
\hline $\begin{array}{l}\text { Maaf, saya harus pergi. } \\
\text { "Excuse me, I have to go now" }\end{array}$ & $\begin{array}{l}\text { Maaf, saya ada urusan lain. } \\
\text { "Excuse me, I have something else to do" }\end{array}$ \\
\hline $\begin{array}{l}\text { Sudah tua. } \\
\text { "Already old" }\end{array}$ & $\begin{array}{l}\text { Tidak begitu muda. } \\
\text { "Not very young", }\end{array}$ \\
\hline
\end{tabular}


Table 5. Meaning-based utterances.

\begin{tabular}{cc}
\hline Literal utterances & Non-literal utterances \\
\hline $\begin{array}{c}\text { Koruptor merugikan negara. } \\
\text { "Corruptors corrupt a country" }\end{array}$ & $\begin{array}{c}\text { Tikus berdasi merugikan negara. } \\
\text { "Rats in the government corrupt a country" }\end{array}$ \\
\hline
\end{tabular}

Table 6. More examples on meaning-based utterances.

\begin{tabular}{|c|c|}
\hline Literal utterances & Non-literal utterances \\
\hline $\begin{array}{l}\text { Pelari itu tidak kenal lelah. } \\
\text { "That runner is never tired" }\end{array}$ & $\begin{array}{l}\text { Pelari itu seperti kuda. } \\
\text { "That runner is like a horse" }\end{array}$ \\
\hline $\begin{array}{l}\text { Selalu datang terlambat. } \\
\text { "Always come late" }\end{array}$ & $\begin{array}{l}\text { Pakai jam karet. } \\
\text { "Have a rubber time" }\end{array}$ \\
\hline $\begin{array}{l}\text { Terlalu banyak berbicara. } \\
\text { "Talk too much" }\end{array}$ & $\begin{array}{l}\text { Tong kosong berbunyi nyaring. } \\
\text { "A gasbag" }\end{array}$ \\
\hline $\begin{array}{l}\text { Kencing. } \\
\text { "Urinate" }\end{array}$ & $\begin{array}{l}\text { Buang air kecil. } \\
\text { "Pass water" }\end{array}$ \\
\hline $\begin{array}{l}\text { Toilet/WC. } \\
\text { "Toilet/bathroom" }\end{array}$ & $\begin{array}{l}\text { Kamar kecil. } \\
\text { "Restroom" }\end{array}$ \\
\hline $\begin{array}{l}\text { Mau ke kamar mandi. } \\
\text { "Go to the bathroom" }\end{array}$ & $\begin{array}{l}\text { Mau ke belakang. } \\
\text { "Go wash one's hands" }\end{array}$ \\
\hline $\begin{array}{l}\text { Naik pesawat ke Singapura. } \\
\text { "Take a plane to Singapore" }\end{array}$ & $\begin{array}{l}\text { Terbang ke Singapura. } \\
\text { "Fly to Singapore" }\end{array}$ \\
\hline $\begin{array}{l}\text { Menyelesaikan masalah kecil secaraberlebihan. } \\
\text { "Settle a minor problem in a super fluousmanner" }\end{array}$ & $\begin{array}{l}\text { Membunuh tikus dengan membakar gudang. } \\
\text { "Burn the warehouse to kill a rat" }\end{array}$ \\
\hline $\begin{array}{l}\text { Pemuda itu besar, tegap, kuat, dan gagah. } \\
\text { "That young man is big, strong, and steady" }\end{array}$ & $\begin{array}{l}\text { Pemuda itu Superman. } \\
\text { "That young man is Superman" }\end{array}$ \\
\hline $\begin{array}{l}\text { Marah dan melabrak apa saja. } \\
\text { "Be mad and destroy everything" }\end{array}$ & $\begin{array}{l}\text { Membabi buta. } \\
\text { "Run amuck" }\end{array}$ \\
\hline
\end{tabular}

context, to maintain their interpersonal face as well as their social face (Jumanto, Pragmatics: Linguistic World is Broad, 2011b). Politeness in the Indonesian language is basically distant language and close language together in context, as proposed by Jumanto (Jumanto, Pragmatics and Character Language Building, 2011c). Distant language and close language refer to and derive from the notion social distance, i.e. the physical as well as psychological distance between the speaker and the hearer.

Pragmatics regards a diglossic situation in a speech society as having the two variants of language above. Distant language refers to formal, indirect, and non-literal utterances, while close language refers to informal, direct, and literal utterances. As referring to formal, indirect, and non-literal utterances, distant language is usually carefully elaborated and uses safe and common topics. Meanwhile, as referring to informal, direct, and literal utterances, close language usually involves contractions, slangs, reverse-ups, changes, taboos, swearing, fwords, and uses any topics, personal and private (Jumanto, Pragmatics and Character Language Building, 2011c). The speaker tends to use distant language to the hearers with power factor (superiors); on the other hand, the speaker tends to use close language to the hearers with solidarity factor (close hearers). Examples of superiors are our bosses, our supervisors, our parents, and others, those who can relatively be close or not close to us. Examples of subordinates are our employees, our younger siblings, our servants, and others, those who can relatively be close or not close to us ${ }^{5}$.

From the accounts above, we can see clearly that distant language and close language are in line with distancing politeness and closeness politeness. Distant language brings politeness, and close language brings

\footnotetext{
${ }^{5}$ Adopted and adapted from Brown and Gilman (Brown \& Gilman, 1968).
} 
friendship or camaraderie (Jumanto, Teaching a Character BIPA (Indonesian for Non-Native Speakers), 2012). Distant language and close language to show politeness and camaraderie finally meet the demand of language as a means of communication, i.e. a real-life everyday use of language in all situations or pragmatic use of language in a diglossic situation.

Back to politeness and camaraderie in the Indonesian language, we should be aware of the two variants of language above; and therefore, to find out the distant Indonesian language and the close Indonesian language, we should relate the types of forms of utterances in the Indonesian language with politeness and camaraderie. A probable data-based illustration is shown in Table 7.

From the categories illustrated in Table 7 we can say that the distant Indonesian language (politeness) tends to have formal, indirect, and non-literal utterances, while the close Indonesian language (camaraderie) tends to have informal, direct, and literal utterances, the tendencies of which can be shown in Table 8.

With reference to the distant Indonesian language and the close Indonesian language illustrated in Table 8, we can transfer the previous data of utterances into three derivative tables. Here, for more ease to say and to learn, we refer the utterances in the three tables to the so-called distant utterances and close utterances. Distant utterances bring politeness, while close utterances bring camaraderie, as illustrated in Tables 9-11.

\subsubsection{Impoliteness in Indonesian Language}

Politeness in using the Indonesian language happens when we use the distant Indonesian language and the close Indonesian language eligibly, i.e. when we use the distant language and the close language to superiors and close hearers respectively (Jumanto, Teaching a Character BIPA (Indonesian for Non-Native Speakers), 2012). Here, as we speak of politeness and camaraderie in the Indonesian language, the Indonesian speakers adjust their utterances to a particular situation that may call. They can perform the so-called code-switching, whether to use the distant Indonesian language or to use the close Indonesian language.

Impoliteness in using the Indonesian language happens when we do not learn the distant language and the close language. When we use the close language to superiors, probably due to our lack of knowledge about distant Indonesian language, we are being not polite or we are being rude, or impoliteness happens. On the other instance, when we use the distant language to close hearers, probably intentionally due to some interpersonal friction, we are also being not polite or impoliteness (or irony) happens. In this case, we are trying to be distant to close hearers. Awkwardness is in the air and there is usually less harmony between us.

Illustrations on rude situations and awkward situations in using Indonesian language are given below.

1) Rude Situations (Impoliteness): Using the Close Indonesian Language to Superiors

Examples of rude situations are as follows:

a) "Cepet baikan, ya Pak Bud!" (?)

"Better soon, OK, Mr. Bud!" (?)

[It should be:]

"Semoga segera sembuh, Bapak Budi."

"May you get better soon, Mister Budi."

b) "Saya tidak setuju dengan Anda." (?)

"I do not agree with you." (?)

[It should be:]

"Menurut saya, sebaiknya begini..."

"I think that it is better like this..."

Table 7. More examples on meaning-based utterances.

\begin{tabular}{ccc}
\hline Types of utterances & Politeness (to superiors) & Camaraderie (to close hearers) \\
formality-based & formal utterances & informal utterances \\
directness-based & indirect utterances & literal utterances \\
meaning-based & non-literal utterances & lites \\
\hline
\end{tabular}

${ }^{6} \mathrm{~A}$ query (?) is used here to show a rude or an awkward situation that may happen. 
Table 8. Types of forms of utterances in Indonesian language in relation with distant language and close language.

\begin{tabular}{cc}
\hline Types of language & Types of forms of utterances \\
\hline Distant Indonesian language & formal utterances, indirect utterances, non-literal utterances \\
Close Indonesian language & informal utterances, direct utterances, literal utterances \\
\hline
\end{tabular}

Table 9. Formality-based utterances in Indonesian language in relation with politeness and camaraderie.

\begin{tabular}{|c|c|}
\hline $\begin{array}{l}\text { Distant Indonesian language } \\
\text { (politeness) with formal utterances }\end{array}$ & $\begin{array}{l}\text { Close Indonesian language } \\
\text { (camaraderie) with informal utterances }\end{array}$ \\
\hline $\begin{array}{l}\text { Saya mengucapkanterima kasihbanyak } \\
\text { "I thank you very much" }\end{array}$ & $\begin{array}{l}\text { Terima kasih; Makasih; Kamsia; Tks; Thanks; Thx } \\
\text { "Thank you"; "Thanks"; "Thx" }\end{array}$ \\
\hline $\begin{array}{l}\text { memberikan } \\
\text { "giving"; "give them" }\end{array}$ & $\begin{array}{l}\text { berikan; beri; kasihkan; kasih } \\
\text { "givin"; "giv’em" }\end{array}$ \\
\hline $\begin{array}{l}\text { Selamat pagi! } \\
\text { "Good morning!" }\end{array}$ & $\begin{array}{l}\text { Met pagi!; Pagi! } \\
\text { "Morning!" }\end{array}$ \\
\hline $\begin{array}{l}\text { Semoga Anda segera sembuh } \\
\text { "May you get better soon" }\end{array}$ & $\begin{array}{l}\text { Cepet sembuh; Cepet baikan; Lekas sehat } \\
\text { "Get better soon"; "Better soon" }\end{array}$ \\
\hline $\begin{array}{l}\text { membantu } \\
\text { "helping"; "help them" }\end{array}$ & $\begin{array}{l}\text { mbantu; bantu } \\
\text { "helpin"; "help'em" }\end{array}$ \\
\hline $\begin{array}{l}\text { lelah sekali } \\
\text { "extremely tired" }\end{array}$ & $\begin{array}{l}\text { capek banget; ka-o; ngos-ngosan } \\
\text { "exhausted" }\end{array}$ \\
\hline $\begin{array}{l}\text { berlebihan } \\
\text { "superfluous" }\end{array}$ & $\begin{array}{c}\text { lebay } \\
{[?]}\end{array}$ \\
\hline $\begin{array}{l}\text { jarang dibelai } \\
\text { "seldom cared for" }\end{array}$ & $\begin{array}{c}\text { jablay } \\
{[?]}\end{array}$ \\
\hline $\begin{array}{c}\text { tidak } \\
\text { "No, I do not" }\end{array}$ & $\begin{array}{l}\text { tak; tdk; nggak; gak } \\
\text { "No"; "I don't"; "don't" }\end{array}$ \\
\hline $\begin{array}{l}\text { meskipun } \\
\text { "although"; "even though" }\end{array}$ & $\begin{array}{l}\text { meski; mskpn } \\
\text { "though" }\end{array}$ \\
\hline $\begin{array}{c}\text { tetapi } \\
\text { "however", "nevertheless" }\end{array}$ & $\begin{array}{l}\text { tapi; tp; but } \\
\text { "but" }\end{array}$ \\
\hline $\begin{array}{l}\text { ayah } \\
\text { "father" }\end{array}$ & $\begin{array}{l}\text { yah; papa; daddy; bokap } \\
\text { "daddy", "dad" }\end{array}$ \\
\hline $\begin{array}{c}\text { ibu } \\
\text { "mother" }\end{array}$ & $\begin{array}{l}\text { bu; mama; mammy; nyokap } \\
\text { "mommy"; "mom" }\end{array}$ \\
\hline $\begin{array}{l}\text { Bapak Budi } \\
\text { "Mister Budi" }\end{array}$ & $\begin{array}{l}\text { Pak Budi; P Budi } \\
\text { "Mr. Budi" }\end{array}$ \\
\hline $\begin{array}{l}\text { Ibu Rini } \\
\text { "Mistress Rini" }\end{array}$ & $\begin{array}{l}\text { Bu Rini; B Rini } \\
\text { "Ms. Rini" }\end{array}$ \\
\hline $\begin{array}{l}\text { Saya } \\
\text { "I would } \cdots "\end{array}$ & $\begin{array}{l}\text { Aku; Gue; Ai; Ike } \\
\text { "I will .."” }\end{array}$ \\
\hline $\begin{array}{l}\text { Anda } \\
\text { "You would } . . "\end{array}$ & $\begin{array}{l}\text { Kamu; Lu; Situ; You } \\
\text { "You will } \cdots "\end{array}$ \\
\hline $\begin{array}{l}\text { Saudara } \\
\text { "You would } \cdots "\end{array}$ & $\begin{array}{c}\mathrm{Sdr} \\
\text { "You will } \ldots "\end{array}$ \\
\hline $\begin{array}{l}\text { dan sebagainya } \\
\text { "et cetera" }\end{array}$ & $\begin{array}{l}\text { dsb } \\
\text { "etc." }\end{array}$ \\
\hline
\end{tabular}


Table 10. Directness-based utterances in Indonesian language in relation with politeness and camaraderie.

\begin{tabular}{|c|c|}
\hline $\begin{array}{l}\text { Close Indonesian language } \\
\text { (camaraderie) with direct utterances }\end{array}$ & $\begin{array}{l}\text { Distant Indonesian language } \\
\text { (politeness) with indirect utterances }\end{array}$ \\
\hline $\begin{array}{l}\text { Saya tidak setuju dengan Anda. } \\
\text { "I do not agree with you" }\end{array}$ & $\begin{array}{l}\text { Menurut saya, sebaiknya begini... } \\
\text { "I think that it is better like this } \cdots \text { " }\end{array}$ \\
\hline $\begin{array}{l}\text { Saya sedang sibuk dan tidak bias diganggu sekarang. } \\
\text { "I am busy. You should not disturb me now" }\end{array}$ & $\begin{array}{l}\text { Bagaimana jika besok saja? } \\
\text { "What if we do this tomorrow?" }\end{array}$ \\
\hline $\begin{array}{l}\text { Tolong hidupkan AC-nya! } \\
\text { "Please turn on the AC!" }\end{array}$ & $\begin{array}{l}\text { Ruangannya kok panas, ya. } \\
\text { "It is hot here, isn't it?" }\end{array}$ \\
\hline $\begin{array}{l}\text { Cinta mereka tidak serius. } \\
\text { "Their love is not very serious" }\end{array}$ & $\begin{array}{l}\text { Mereka sedang cinta monyet. } \\
\text { "They are in puppy love" }\end{array}$ \\
\hline $\begin{array}{l}\text { Panggilkan Pak Kebun! } \\
\text { "Call the gardener!" }\end{array}$ & $\begin{array}{l}\text { Pak Kebun di mana, ya? } \\
\text { "Where is the gardener?" }\end{array}$ \\
\hline $\begin{array}{l}\text { Saya tidak minum kopi. } \\
\text { "I do not drink coffee" }\end{array}$ & $\begin{array}{l}\text { Bisa minuman yang lain? } \\
\text { "Do you have something else to drink?" }\end{array}$ \\
\hline $\begin{array}{l}\text { Lama. } \\
\text { "Long time" }\end{array}$ & $\begin{array}{l}\text { Tidak sebentar. } \\
\text { "Not a short time" }\end{array}$ \\
\hline $\begin{array}{l}\text { Terlambat. } \\
\text { "Late" }\end{array}$ & $\begin{array}{l}\text { Tidak tepat waktu. } \\
\text { "Not on time" }\end{array}$ \\
\hline $\begin{array}{l}\text { Bodoh. } \\
\text { "Stupid" }\end{array}$ & $\begin{array}{l}\text { Tidak begitu pintar. } \\
\text { "Not very smart" }\end{array}$ \\
\hline $\begin{array}{l}\text { Maaf, saya harus pergi. } \\
\text { "Excuse me, I have to go now" }\end{array}$ & $\begin{array}{l}\text { Maaf, saya ada urusan lain. } \\
\text { "Excuse me, I have something else to do" }\end{array}$ \\
\hline $\begin{array}{l}\text { Sudah tua. } \\
\text { "Already old" }\end{array}$ & $\begin{array}{l}\text { Tidak begitu muda. } \\
\text { "Not very young" }\end{array}$ \\
\hline
\end{tabular}

c) "Maaf, Pak. Saya mau ke WC dulu." (?)

"Excuse me, Sir. I want to go to the toilet first." (?)

[It should be:]

"Maaf, Bapak. Saya ijin ke kamar kecil dulu."

"Excuse me, Sir. May I go to the restroom, please?"

Rude situations may happen in the three utterances above, as the speakers are speaking to superiors by using a close language. Here, a) "Cepet baikan, ya Pak Bud!”, b) "Saya tidak setuju dengan Anda.", and c) "Maaf, Pak. Saya mau ke WC dulu.” are all of close language, i.e. informal, direct, and literal respectively.

2) Awkward Situations (Impoliteness): Using the Distant Indonesian Language to Close Hearers

Examples of awkward situations are as follows:

a) "Saya mengucapkan terima kasih banyak atas bantuan Anda, ya Susanto!" (?)

"I thank you very much for your help, OK, Susanto!" (?)

[It should be:]

"Makasih banget bantuanmu, ya Sus!"

"Thanks so much for your help, OK, Sus!"

b) "Ruangannya kok panas, ya." (?)

"It is hot here, isn't it." (?)

[It should be:]

"Tolong hidupkan AC-nya!"

"Please turn on the AC!" 
c) "Wah, Anda pakai jam karet terus, nih!" (?)

"Well, you always have rubber time, don't you!" (?)

[It should be:]

"Ngapain kamu kok datang terlambat terus?"

"Why the hell d'you always come late?"

Awkward situations may happen in the three utterances above, as the speakers are speaking to close hearers by using a distant language. Here, a) "Saya mengucapkan terima kasih banyak atas bantuan Anda, ya Susanto!", b) "Ruangannya kok panas, ya.", and c) "Wah, Anda pakai jam karet terus, nih!" are all of distant language, i.e. formal, indirect, and non-literal respectively.

\subsubsection{Cases of Confusion Due to Factors of Power and Solidarity: Code-Mixing for Camaraderie} In the case that confusion happens due to the factors of power and solidarity in the hearer, i.e. whether a superior is close or a close hearer has power, for example, the so-called code-mixing happens. However, as the terminology suggests, the code-mixing in language use belongs to informality, thus using a close language (camaraderie) ${ }^{7}$. Cases like these usually happen between close speakers, i.e. a superior to a close subordinate or a subordinate to a close superior. Examples on these cases are given below:

a) "Aku mengucapkan terima kasih banyak atas bantuanmu, ya Sus!"

"I thank you very much for your help, OK, Sus!"

Table 11. Meaning-based utterances in Indonesian languagein relation with politeness and camaraderie.

\begin{tabular}{|c|c|}
\hline $\begin{array}{l}\text { Close Indonesian language } \\
\text { (camaraderie) with literal utterances }\end{array}$ & $\begin{array}{l}\text { Distant Indonesian language } \\
\text { (politeness) with non-literal utterances }\end{array}$ \\
\hline $\begin{array}{l}\text { Tikus membawa penyakit. } \\
\text { "Rats carry disease" }\end{array}$ & $\begin{array}{l}\text { Tikus berdasi merugikan negara. } \\
\text { "Rats in the government corrupt a country" }\end{array}$ \\
\hline $\begin{array}{l}\text { Pelari itu tidak kenal lelah. } \\
\text { "That runner is never tired" }\end{array}$ & $\begin{array}{l}\text { Pelari itu seperti kuda. } \\
\text { "That runner is like a horse" }\end{array}$ \\
\hline $\begin{array}{l}\text { Selalu datang terlambat. } \\
\text { "Always come late" }\end{array}$ & $\begin{array}{l}\text { Pakai jam karet. } \\
\text { "Have a rubber time" }\end{array}$ \\
\hline $\begin{array}{l}\text { Terlalu banyak berbicara. } \\
\text { "Talk too much" }\end{array}$ & $\begin{array}{l}\text { Tong kosong berbunyi nyaring. } \\
\text { "A gasbag" }\end{array}$ \\
\hline $\begin{array}{l}\text { Kencing. } \\
\text { "Urinate" }\end{array}$ & $\begin{array}{l}\text { Buang air kecil. } \\
\text { "Pass water" }\end{array}$ \\
\hline $\begin{array}{l}\text { Toilet/WC. } \\
\text { "Toilet/bathroom" }\end{array}$ & $\begin{array}{l}\text { Kamar kecil. } \\
\text { "Restroom" }\end{array}$ \\
\hline $\begin{array}{l}\text { Mau ke kamar mandi. } \\
\text { "Go to the bathroom" }\end{array}$ & $\begin{array}{l}\text { Mau ke belakang. } \\
\text { "Go wash one's hands" }\end{array}$ \\
\hline $\begin{array}{l}\text { Naik pesawat ke Singapura. } \\
\text { "Take a plane to Singapore" }\end{array}$ & $\begin{array}{l}\text { Terbang ke Singapura. } \\
\text { "Fly to Singapore" }\end{array}$ \\
\hline $\begin{array}{l}\text { Menyelesaikan masalah kecil secara berlebihan. } \\
\text { "Settle a minor problem in a superfluous manner" }\end{array}$ & $\begin{array}{l}\text { Membunuh tikus dengan membakar gudang. } \\
\text { "Burn the warehouse to kill a rat" }\end{array}$ \\
\hline $\begin{array}{l}\text { Pemuda itu besar, tegap, kuat, dan gagah. } \\
\text { "That young man is big, strong, and steady" }\end{array}$ & $\begin{array}{l}\text { Pemuda itu Superman. } \\
\text { "That young man is Superman" }\end{array}$ \\
\hline $\begin{array}{l}\text { Marah dan melabrak apa saja. } \\
\text { "Be mad and destroy everything" }\end{array}$ & $\begin{array}{l}\text { Membabi buta. } \\
\text { "Run amuck" }\end{array}$ \\
\hline
\end{tabular}

\footnotetext{
${ }^{7}$ Analogy of this is just like wearing a T-shirt and a tie.Using a language is, indeed, like wearing clothes (Jumanto, Pragmatics: Linguistic
} World is Broad, 2011b). 
This is a probable situation between a superiorto a close subordinate, i.e. using a code-mixing of distant and close language. Here the expressions "Aku", "OK", "Sus", and "-mu" are informal, while the expression "mengucapkan terima kasih banyak atas bantuan-" is formal.

b) "Saya tidak setuju dengan rencana kamu, lho."

"I do not agree on your plan, you know."

This is another probable situation between a subordinateto a close superior, i.e. using a code-mixing of distant and close language. Here the expressions "setuju", "kamu", and "lho" are informal, while the expressions "saya" and "tidak" are formal. The whole expression "Saya tidak setuju dengan rencana kamu, lho" itself is a direct utterance, thus used between close speakers.

c) "Wah, kamu ini pakai jam karet terus, sih!"

"Well, you always have rubber time, you see!"

The example (3) above is another probable situation between a superiorto a close subordinate, i.e. using a code-mixing of distant and close language. Though the expressions "wah", "kamu", and "sih" are informal (thus, part of close language), the expression "jam karet" is non-literal, and thus, part of distant language.

From the three examples above, however, as the code-mixing happens only between close speakers, awkwardness does not usually happen and politeness between them is maintained. Camaraderie instills. Language use is a matter of probabilities.

\subsection{Phases of Character Language: A Proposal to the Open Linguistic World}

The building of a character language means applying the accounts on politeness, camaraderie, and impoliteness discussed above in verbal interactions so that distant language and close language are learned, internalized, personalized, and socialized or practiced in everyday life, and, therefore, rude situations as well as awkward situations can be avoided. Many parties are involved in this verbal social project: parents, teachers, communities, societies, and the authorities: the school managers, the local government, and the national government. Pragmatics is applied in this character language building in a context as if a native speaker is trying to acquire their language.

The pragmatic aspects to be applied are the fourstrategies, i.e. 1) elaboration of meaning and form strategies, 2) distant language and close language strategies, 3) politeness and camaraderie strategies, 4) object language and metalanguage strategies. The strategies function as building blocks of a character language building, the developing steps of which are the six phases of verbal social project as follows:

\subsubsection{Interaction Phase}

In this early phase, elaboration of meaning is more important than elaboration of form. Close language strategies should also be more emphasized in the daily experience than distant language strategies, and therefore, camaraderie strategies are more elaborated. As the learning speaker just starts building their character language, object language and metalanguage should be experienced in a 75:25 ratio of probabilities. The parties to help encouraging this phase are parents and close communities.

\subsubsection{Teaching-and-Learning Process Phase}

This phase is done at school, i.e. the teaching-and-learning phase. In this phase, elaborations of meaning and form strategies, distant language and close language strategies, politeness and camaraderie strategies, and object language and metalanguage strategies are equally experienced by the learning speaker of a character language. The speaker should experience an equal 50:50 ratio of probabilities encouraged by their character language teacher. The parties most responsible for helping encouraging this phase are teachers, and all the authorities, parents, close and distant communities, and societies.

\subsubsection{Evaluation Phase}

This phase is also done at school, i.e. the evaluation phase. The evaluation phase here is of formal and structured evaluation processes: progress, mid-term, and final-term evaluations. The elaborations of meaning and form strategies, distant language and close language strategies, politeness and camaraderie strategies, and object language and metalanguage strategies are equally evaluated by the teacher teaching a character language. The 
teacher should evaluate an equal 50:50 ratio of probabilities of character language material having learned by the learning speaker. Written reports are given upon the evaluation processes. The parties most responsible for helping encouraging this phase are teachers, and all the authorities.

\subsubsection{Re-Evaluation Phase}

This phase is also done at school, i.e. the re-evaluation phase. The re-evaluation phase here is an informal and unstructured evaluation atmosphere: in fun classrooms, in the school doorways, in sudden encounters between the teacher and the learning speaker, in the school yard, and in other school spaces at relaxed situations. The teacher should verify on the learning speaker's verbal performance on their character language in indirect and relaxed manners: whether the verbal performance is appropriate or not yet. When doing so, the teacher should minimize the threat to the learning speaker. Compliments and discussions are given upon the learning speaker's verbal performance. The parties most responsible for helping encouraging this phase are teachers, and all the authorities.

\subsubsection{Verification Phase}

This phase is done everywhere, i.e. the verification phase. This phase is to strengthen the re-evaluation phase at school. The verification phase should be done everywhere by the character language competent speakers upon the verbal performance of the learning speakers. Thus, every competent speaker is responsible for encouraging the learning speaker to complete their character language building. This phase is also done in an informal and unstructured atmosphere everywhere in the country. The verification should also be done in indirect and relaxed manners. Compliments and discussions should also be given upon the learning speaker's verbal performance. All the parties are most responsible for encouraging this phase.

\subsubsection{Selection Phase}

This is the final phase of the character language building project, i.e. the selection phase. This phase is for the speaker to apply the character language they have just completed learning, in a particular situation that may call. The speakers are now smart enough in using the language pragmatically, as they have equipped themselves with all the strategies required for character language use in a diglossic situation. The competent speaker may now select to use either distant language or close language, i.e. either formal utterances, indirect utterances, and nonliteral utterances in the formal situations, or informal utterances, direct utterances, and literal utterances in the informal situations. In this final phase, all parties as well as members of the speech society are responsible for encouraging one another in using and maintaining the character language.

\section{Conclusion}

The character language building proposed and discussed in this paper is a verbal social project. A social project here implies that the whole speech society is invited as well as involved in the project: parents, teachers, communities, societies, and the authorities: the school managers, the local government, and the national government.

This verbal social project is costly but is not impossible to carry out. The four pragmatic strategies elaborated as the building blocks of character language building are worth applying in the efforts to equip the state children of tomorrow with a character language for the future of a character nation.

A character language is inevitably important as part of character nation building. In this light, pragmatics serves to character nation building in the scope of verbal performances of a competent character speaker. A competent character speaker is a good speaker who in time will probably be a good character leader in a particular country.

As a character language equips the speakers with politeness and camaraderie and with awareness of avoiding impoliteness, both in rude situations and in awkward situations, the teaching and learning of it, and later the acquisition of it, will contribute to interpersonal, communal, social, and, in time, national harmony.

\section{Acknowledgements}

I would like to acknowledge all the distinguished people here for contributing their thoughts as well as precious opinions to the linguistic world I have academically lived in. The first group is nine English native speakers: (1) Samantha Custer (New England, US), John Custer (Pennsylvania, US), Bradford Sincock (Michigan, US), Pa- 
tricia Mary O’Dwyer (South Ireland, GB), Patrick Bradley (Scotland, GB), Simon Colledge (London, UK, GB), Ian Briggs (Northern Territory, Australia), Anastasia de Guise (New South Wales, Australia), and Katrina Michelle Langford (Victoria, Australia). They have inspired me on how a linguist should perform in the linguistic world as well as on how I should learn more to observe people talking and to get real-life lessons for developing the pragmatic world.

I would also like to extend my gratitude to the second group of nine Indonesian professionals, Indonesian native speakers, without whom my linguistic world is not as enough as it is today: (1) Putri Mayangsari (freelance interpreter, Jakarta), Ria Herwandar (language consultant, Jakarta), Joseph Poerwono (company manager, Jakarta), Soetanto Hoetomo (school manager, Jakarta), Esther D. Tamtama (lecturer, Semarang), Herni Ambarwati (senior secretary, Semarang), Agus Sururi (hotel manager, Semarang), Didi Pribadi (restaurant manager, Semarang), and Siti Subiantari (liaison/guide, Jakarta).

Last but not least, I owe a lot to former linguists as well as researchers, whose works are both significant and helpful for making this article happen. May God the Almighty be with and bless you all.

\section{References}

Arndt, H., \& Janney, R. (1985). Politeness Revisited: Cross-Modal Supportive Strategies. International Review of Applied Linguistics in Language Teaching, 23, 281-300.

Austin, J. (1957). How to Do Things with Words. Oxford: Oxford University Press.

Axtell, R. E. (1995). Do's and Taboos of Using English around the World. New York: John Wiley \& Sons, Inc.

Blum-Kulka, S. (1992). The Metapragmatics of Politeness in Israeli Society. In S. I. Richard Watts (Ed.), Politeness in Language: Studies in its History, Theory, and Practice. Berlin: Mouton de Gruyter.

Boomfield, L. (1930). Language. New York: Holt.

Brown, P., \& Levinson, S. C. (1987). Politeness: Some Universals in Language Usage. New York: Cambridge University Press.

Brown, R., \& Gilman, A. (1968). The Pronouns of Power and Solidarity. In J. A. Fishman (Ed.), Readings in the Sociology of Language (pp. 252-275). The Hague: Mouton \& Co. N.V. Publishers. http://dx.doi.org/10.1515/9783110805376.252

Bühler, K. (1918). Theory of Language: The Representational Function of Language. Amsterdam: John Benjamins Publishing Co.

CALD (2008). Cambridge Advanced Learner's Dictionary. Cambridge: Cambridge University Press.

Carter, R. E. (1997). Working with Texts: A Core Book For language Analysis. London: Routledge. http://dx.doi.org/10.4324/9780203468470

Chomsky, N. (1950). Aspects of the Theory of Syntax. Cambridge: MIT Press.

CoBuild CoBuild English Dictionary (2003).

Cook, G. (1989). Discourse. Oxford: Oxford University Press.

Coupland, J. (2000). Small Talk. Harlow: Pearson Education Limited.

de Saussure, F. (1916). Pengantar linguistik Umum. Yogyakarta: Yogyakarta: Gadjah Mada University Press.

Duranti, A. (1998). Communicative Competence. In J. L. Mey (Ed.), Concise Encyclopedia of Pragmatics (pp. 147-148). Amsterdam: Elsevier.

Eelen, G. (2001). A Critique of Politeness Theories. Manchester: St. Jerome Publishing.

Fraser, B., \& Nolen, W. (1981). The Association of Deference with Linguistic Form. International Journal of the Sociology of Language, 1981, 93-109.

Fries, C. C. (1979). Review of Grammatical Analysis. In K. L. Pike, \& E. G. Pike (Eds.), Language (Vol. 55, pp. 907-911). London: Longman.

Goffman, E. (1959). The Presentation of Self in Everyday Life. New York: Anchor Books.

Goffman, E. (1967). Interaction Ritual: Essays on Face to Face Behavior. New York: Anchor Books.

Grice, H. P. (1975). Logic and Conversation. In P. Cole, \& J. Morgan (Eds.), Syntax and Semantics, Speech Acts (Vol. 3, pp. 33-49). New York: Academic Press.

Gu, Y.G. (1990). Politeness Phenomena in Modern Chinese. Journal of Pragmatics, 14, 237-257. http://dx.doi.org/10.1016/0378-2166(90)90082-O

Gunarwan, A. (2001). Implicatures of Linguistic Codes Selection in Some Dialogues of Ludruk. PELLBA, 14, 23-35.

Gunarwan, A. (2005). Articles on Loose Papers in PhD Study Classes, University of Indonesia. Papers, Jakarta: University 
of Indonesia.

Hinkel, E. (1999). Culture in Second Language Teaching and Learning. Cambridge: Cambridge University Press.

Holmes, J. (1992). An Introduction to Sociolinguistics. London: Longman Group Ltd.

Hornby, A. (1987). Oxford Advanced Learner's Dictionary of Current English. Oxford: Oxford University Press.

Hymes, D. (1972). On Communicative Competence. In J. Pride, \& J. Holmes (Eds.), Sociolinguistics (pp. 269-285). Harmondsworth: Penguin Books.

Hymes, D. (1974). Foundations in Sociolinguistics. Philadelphia, PA: University of Pennsylvania Press.

Ide, S. (1989). Formal Forms and Discernment: Two Neglected Aspects of Universals of Linguistic Politeness. Multilingua, 8, 223-248. http://dx.doi.org/10.1515/mult.1989.8.2-3.223

Jakobson, R. (1960). Concluding Statement: Linguistics and Poetics. In T. Sebeok (Ed.), Style in Language (pp. 350-377). Cambridge: MIT Press.

Jumanto, J. (2006). Komunikasi Fatis di Kalangan Penutur Jati Bahasa Inggris. Unpublished PhD Dissertation, Jakarta: Universitas Indonesia.

Jumanto, J. (2008). Phatic Communication among English Native Speakers. Semarang: WorldPro Publishing.

Jumanto, J. (2010). Language of Advertising: An Ideology Critic. In Languages and Science (BIP) (pp. 11-19). Semaranga: Akaba 17 Semarang.

Jumanto, J. (2011a). Discourse Analysis and Ideology Critics. In Lingua Komunika (pp. 44-51). Semarang: University of 17 August 1945.

Jumanto, J. (2011b). Pragmatics: Linguistic World Is Broad. Semarang: WorldPro Publishing.

Jumanto, J. (2011c). Pragmatics and Character Language Building. The 58th TEFLIN International Conference on Language Teaching and Character Building (pp. 329-340). Semarang: IKIP PGRI College.

Jumanto, J. (2012). Teaching a Character BIPA (Indonesian for Non-Native Speakers). The 2012 KIPBIPA VIII-ASILE International Conference (pp. 1-20). Salatiga: UKSW University.

Lakoff, R. T. (1990). Talking Power: The Politics of Language in Our Lives. Glasgow: HarperCollins.

Leech, G. (1983). Principles of Pragmatics. New York: Longman Group Limited.

Lincoln, Y., \& Guba, E. (1985). Naturalistic Inquiry. Beverly Hills, CA: Sage.

Malinowski, B. (1923). The Problem of Meaning in Primitive Languages. In C. K. Ogden, \& I. A. Richards (Eds.), The Meaning of Meaning (pp. 296-336). London: K. Paul, Trend, Trubner.

Mey, J. L. (2001). Pragmatics: An Introduction (2nd ed.). Oxford: Blackwell.

Morris, C. (1946). Signs, Language, and Behavior. New York: Prentice-Hall.

Ogden, C. K., \& Richards, A. (1923). The Meaning of Meaning. London: K. Paul, Trend, Trubner.

OLPD (1987). Oxford Learner's Pocket Dictionary. Oxford: Oxford University Press.

Renkema, J. (1993). Discourse Studies: An Introductory Textbook. Amsterdam: John Benjamins Publishing Company.

Richards, J., Platt, J., \& Platt, H. (1985). Longman Dictionary of Language Teaching and Applied Linguistics. Essex: Longman.

Schiffrin, D. (1994). Approaches to Discourse. Cambridge: Blackwell Publishers.

Searle, J. (1965). Speech Acts. Cambridge: Cambridge University Press.

Spencer-Oatey, H. (1992). Cross-Cultural Politeness: British and Chinese Conceptions of the Tutor-Student Relationship. Unpublished $\mathrm{PhD}$ Thesis, Lancaster: Lancaster University.

Thomas, J. (1996). Meaning in Interaction: An Introduction to Pragmatics. London: Longman.

Thompson, L. (1997). Children Talking: The Development of Pragmatic Competence. London: Multilingual Matters Publisher.

Watts, R. (1989). Relevance and Relational Work: Linguistic Politeness as Politic Behavior. Multilingua, 8, 131-166. http://dx.doi.org/10.1515/mult.1989.8.2-3.131 